\title{
Three-generation experiment showed female C57BL/6J mice drink drainage canal water containing low level of TCDD-like activity causing high pup mortality
}

\author{
Li Huang', Ren Huang², Xin-Ru Ran³, Han-Ying Liu'1, Yu Zhang'², Li-Jun Dai' \\ and Bing Li ${ }^{1}$ \\ ${ }^{1}$ Experimental Animal Research center, Guangzhou Medical College, 195, Dongfeng Road West, Yuexiu district, \\ Guangzhou, 510182, China \\ ${ }^{2}$ Experimental Animal Monitoring Institute, Guangdong Province, 237, Newport Road West, Haizhu district, \\ Guangzhou, 510260, China \\ ${ }^{3}$ Department of Biotechnology, South China Agriculture University, 483, Wushan road, Tianhe district, \\ Guangzhou, 510480, China
}

(Received July 7, 2011; Accepted August 29, 2011)

\begin{abstract}
TCDD), polychlorinated biphenyls (PCBs) and similar compounds are toxic to animals and humans. Based on a yeast reporter system, AhR-activating ligands similar in concentration to $2 \mathrm{ng} / \mathrm{l}$ of TCDD were detected in two canal waters in Guangzhou, China. In this study, a three-generation experiment was conducted to assess the reproductive and developmental risks associated with these waters in C57BL/6J female mice, including female reproduction, pup indices, reproductive hormone levels, and levels of AhR, ARNT, and CYP1A2 in the uterus. Similar reproductive toxic effects were produced in the offspring of mice that drank the canal water as would occur if they drank $2 \mathrm{ng} / \mathrm{l} / \mathrm{day}$ TCDD. The major reproductive indices that were affected included mating time and gestation length over all the generations. A striking finding is the TCDD ( $2 \mathrm{ng} / \mathrm{l})$ and the water samples significantly reduced Day 4 pup survival rates in the F2 and F3. Both TCDD exposure and drinking canal water decreased estradiol-17 $\beta$ (E2) levels in the multiparous females and decreased folliclestimulating hormone (FSH), luteinizing hormone (LH) and E2 levels in the virgin females. Immunochemical staining revealed that the AhR and CYP1A2 positive signals were enhanced, and the ARNT positive signal was weakened in the uteri of mice drinking water with TCDD (2 ng/l) and the canal water samples. These results imply that the canal water contains AhR ligands that could induce similar toxic effects as do low levels of TCDD. Exposure to these contaminants can significantly impair the reproductive health of female mice. Considering this canals are open directly to Pearl River, whether these effects could be caused in human reproduction and development warrants further study.
\end{abstract}

Key words: 2,3,7,8-tetrachlorodibenzo-p-dioxin, Female reproductive toxic, Canal water, Three generation experiment

\section{INTRODUCTION}

2,3,7,8-tetrachlorodibenzo-p-dioxin (TCDD), polychlorinated biphenyls (PCBs) and similar compounds are toxic to animals and humans (Safe, 1994; Birnbaum, 1994). In the environment, these compounds mainly come from industrial air emissions, wastewater discharges, disposal activities, and burning materials containing chlorine, and can persist in the environment for years (Hutzinger et al., 1991). TCDD exposure suppresses the immune system (Holsapple et al., 1999), causes many kinds of cancers (IARC, 1997), and disrupts reproduction (Birnbaum and Tuomisto, 2000). At high doses, TCDD causes death, weight loss, oxidative stress, lymphoid atrophy, gonadal atrophy, cutaneous lesions, fatty liver and gastrointestinal hemorrhage (Birnbaum and Tuomisto, 2000; Niittynen et al., 2007). The toxicological effects are mediated by the aryl hydrocarbon receptor (Ah receptor,

Correspondence: Bing Li (E-mail: libing@gzhmc.edu.cn) 
AhR), a signal transducer and activator of transcription (Birnbaum, 1994; Safe, 1995; Hankinson, 1995). Downstream effects may involve altered patterns of gene expression, cell growth and differentiation, and disruption of steroid hormone and growth factor signal transduction pathways (IARC, 1997; DeVito and Birnbaum,1994).

The Pearl River Delta area in South China is the largest manufacturing center in the world since the $1980 \mathrm{~s}$. PCBs and TCDD-like compounds have accumulated there since that period and may have exerted harmful effects in humans. However, there are limited reports on these effects. It has been reported that the Pearl River Delta water sludge contains substantial amounts of TCDD-like contaminants (Kang et al., 2000). In our previous study using an AhR-driven yeast reporter system (Huang et al., 2004), we evaluated drainage canal water at sites near Guangzhou City in the center of the Pearl River Delta. It is notable that these canals were once be used as waterway in suburb of Guangzhou for transport of farm products. Because the rapid expansion of city residence area and newly opened small manufacturing workshops were merged to the city, the canals were turned to be used as both transport and drainage canals. Because this areas were not included in the city urban planning, and no or less than required wastewater treatment plants were established, the drainage water of both industry and living nature are directly drained to the Pearl River. Two sites were suspected of containing hazardous levels of aromatic hydrocarbon compounds. The level of TCDD-like substances reached $2 \mathrm{ng} / \mathrm{l}$ (Huang et al., 2004). We are now interested in whether this contamination level may affect human health.

The toxicity of TCDD-like contaminants is more severe in developing versus mature systems (Wolf et al., 1999; Hurst et al., 2000). These contaminants decrease fertility, increase prenatal mortality, cause birth defects, and increase the risk for endometriosis (Couture et al., 1990; Fenton et al., 2002; Guo et al., 1999; Heimler et al., 1998; Huisman et al., 1995; Rier et al., 1993). Reproductive organs seem to be more sensitive to TCDD toxicity. In our previous work, we performed a subacute toxic study to evaluat whether low TCDD contamination level could disturb female reproduction. We found that in mice intragastrically administered with TCDD levels above 50 $\mathrm{ng} / \mathrm{l}$ for 8 days, the decidual cell response were dramatically inhibited and the number of implanted embryos decreased during early pregnancy. These levels also significantly decreased the serum progesterone levels but had no obvious effects on the level of serum estradiol. Using the same AhR-driven yeast reporter system, we found that TCDD level in the uterus of NIH mice exposed to TCDD orally during early gestation was equal to the level in the liver, suggesting that TCDD is accumulated in the uterus. It is notable that serum progesterone levels were suppressed at $2 \mathrm{ng} / \mathrm{kg} / \mathrm{d}$, although no decidual cell response suppression was observed (Li et al., 2006). In our preliminary study, decreased fertility was detected in the P1 and P2 generations of mice that drank TCDD (2 ng/l) in water compared to control. These results prompted us to evaluate whether the two canal waters interfere with the female reproductive system in chronically-exposed animals. A three-generation exposure experiment was performed to investigate whether the suspected TCDD-like substances in the two canal waters could affect the reproduction in $\mathrm{C} 57 \mathrm{BL} / 6 \mathrm{~J}$ female mice compared to a standard TCDD control.

\section{MATERIALS AND METHODS}

\section{Materials}

TCDD was purchased from AccuStandard, Inc. (970401R-AC; New Haven, CT, USA) with a reported purity of $99 \%$. TCDD was dissolved with DMSO and then diluted with the municipal drinking water to $2 \mathrm{ng} / \mathrm{l}$ (the TCDD standard). The two canal water samples were collected from two canals in Guangzhou City that flow to the Pearl River during 2004-2006. The water samples were designated as Shijin water and Fangcun water for the specific district they were collected, sterilized and kept in containers at room temperature.

\section{Assaying the water samples by the yeast lacZ assay system}

The yeast reporter system included a Saccharomyces cerevisiae cell stain (YCM3) that was established by Miller (Miller, 1999). Human AhR and Arnt genes and a reporter plasmid containing a lacZ that was controlled by the AhR response element p-TXRE5-Z were stably transfected into yeast. This produced a yeast strain that could detect AhR ligands below $0.01 \mathrm{ng} / \mathrm{l}$. To semi-quantify TCDD, the water samples were collected and used in the yeast culture medium for assaying, using $2 \mathrm{ng} / \mathrm{l}$ of TCDD as a control. Silanized, clear, screw-top vials and reagents (Sigma-Aldrich, St. Louis, MO, USA) were used in the yeast lacZ assay system. The assaying procedure was performed as described (Miller, 1999).

\section{Animal housing and water exposure}

C57BL/6 mice were used in the experiment because this strain is genetically susceptible to toxicities induced by TCDD and related chemicals (Hakk et al., 2009). Female mice at three weeks of age, derived from Experi- 
The low level of TCDD-like activity in drainage canal water causes high postnatal mortality in mice

mental Animal Center at the Guangzhou Medical College (Health certificate number 2003A042), and were reared there (Environmental Certificate number 2003C050). All mice were housed in a 12-hr light/dark cycle at ambient temperatures of $19-23^{\circ} \mathrm{C}$ and relative humidities of $40-70 \%$. Mice were randomly assigned to four groups and housed in plastic shoebox-type cages and provided with ground, wood-nesting material. A basal diet (Hygiene Agency at the Experimental Animal Center, Guangdong province) was available throughout the study.

Water sample was administered ad libitum at concentrations targeted to provide TCDD dose levels of 0 and $2 \mathrm{ng} / \mathrm{l}$. The water collected from a branch of the Pearl River which were approximately equivalent to a concentration of $2 \mathrm{ng} / \mathrm{l}$ of TCDD, was selected based on the results of a subchronic study in NIH mice and a yeast lacZ assay for wastewater. Animals were maintained with the test drinking water for a three-generation study.

\section{Study design}

Four groups of female mice were maintained continuously on the drinking water samples for three generations. P0 adults (40/weaning female/dose level, 10 mice in each group) were maintained ad libitum on tap water and water samples for 7 weeks prior to breeding to produce the F1a litters. Following weaning of the F1a litters, 40 females from each treatment group were selected as the P1 generation and exposed to the test water for 7 weeks from the weaning of the F1a litters. Following 7 weeks of treatment, the P1 adults were bred to produce the F2a litters. After weaning the F2a litters, 40 females from each treatment group were selected as the $\mathrm{P} 2$ generation and exposed to the drinking water for 7 weeks. After 7 weeks of treatment, the P2 adults were bred to produce the F3a litters. Approximately 5 days after weaning, the P0, P1 and $\mathrm{P} 2$ adults were again mated to produce the F1b, F2b and F3b litters (Fig. 1).

Liver, uterus, oviduct and ovary were collected from adults and pups under anesthesia and preserved in a $10 \%$ formalin fixative for pathological analyses on day 35 after the last litter of the respective generation was weaned. Serum was prepared for the determination of reproductive hormone levels by radioimmunoassay.

\section{Female reproduction and development indices}

The female mice $(n=10)$ in each treatment group were mated with normal males with proven fertility, derived from Experimental Animal Center at the Guangzhou Medical College, and were not exposed to any treatment. Each mating (breeding) consisted of 3 consecutive 2-day cohabitation periods and with 2 females with a male in a cage. During cohabitation period, the samples water were

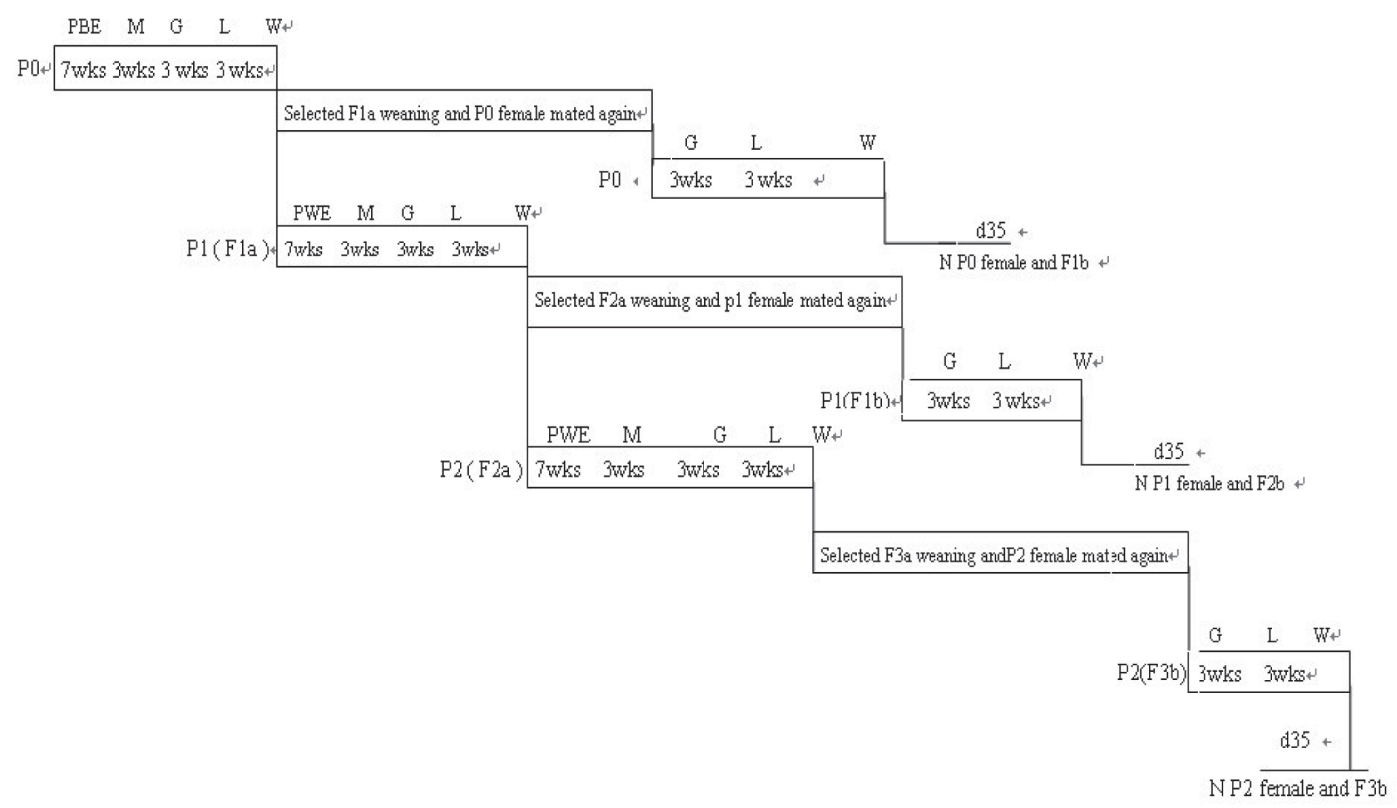

Fig. 1. Three-generation study design for contaminated water. PBE, pre-breed exposure (7 weeks); PWE, post-wean exposure (7 weeks); M, mating (3 weeks); G, gestation (3 weeks); L, lactation (3 weeks); W, weaning; PND, post-natal day; Parental generation $(\mathrm{P})$; Filial generation $(\mathrm{F})$. 
replaced with tapwater for avoid possible effect on male mice. Vaginal plug was checked every morning, and the day of plug was designated as gestation day 0 (GD0). These mice were also checked for survival, signs of vaginal bleeding and so on at every observation. Any visible physical abnormality changes were noted during gestation. Reproductive indices were recorded in adequate time, including Mean Day to Mating, Female Mating Index ((number of females mating /number of cohabited females $) \times 100)$, Female Fertility Index ((numberof pregnant females $/$ number of females mating $) \times 100)$, Gestation Index ((number of females with live born /number of females with evidence of pregnancy) $\times 100)$, and Gestation Length (Robert, 2006).

The developmental indices(Robert, 2006) were examined as soon as possible after delivery. Litter size PND0 ((total number of pups delivered (live and stillborn)/ number of dams that delivered)) and the number of live and dead pups were recorded until each litter was weaned on LD 21. From these data, the Live Birth Index ((number of pups born alive /total number of pups born $) \times 100)$, Day 4 Pup Survival Index ((number of live pups at day $4 /$ number of pups born $) \times 100)$, and Weaning Survival Index ((number of live pups at day 21 /number of pups born $) \times 100$ ) were calculated. (determined on lactation day (LD), inculding $0,1,4$, and 21). The Sex Ratio of male offspring ((number of male offspring/total number of offspring $) \times 100)$ and weight of each pup were determined on $\operatorname{LD} 0,7,14$, and 21 and any visible physical abnormality changes were noted during lactation, repsectively.

\section{Immunohistochemical quantitative evaluation of AhR, ARNT and Cyp1a2}

Immunohistochemical staining evaluations were performed on all of the tissues from the adult P0, P1 and P2 in both control and treated animals. Liver and uterine tissues were fixed in $10 \%$ buffered formalin for 8-16 $\mathrm{h}$, dehydrated and embedded in paraffin. All tissues were serially-sectioned at a $5-\mu \mathrm{m}$ thickness with a rotary microtome. Immunohistochemical analyses for the presence of AhR, ARNT and a cytochrome P450 enzyme (Cyp1a2) in the uteri were performed using VECTASTAIN ABC Kits (VECTOR laboratories Inc., Burlingame, CA, USA) following the manufacturer's guidelines. The specific anti-bodies used in this study were affinity purified goat anti-Ah Receptor (sc-8088) polycloned antibody, goat anti-Arnt(sc-8078) polyclonal antibody (Santa Cruz Biotechnology, Inc., Santa Cruz, CA, USA), and goat anti-rat Cyp1a2 polyclonal antibody (Chemicon
International, Inc., Temecula, CA, USA, LOT: 23101800). Rabbit anti goat IgG biotin conjugated affinity-purified antibody (Chemicon International, Inc. LOT: 23121270) was used as secondary antibody. The sections that were stained for AhR, ARNT, and Cyp1a2 were also counterstained with Mayer's hematoxylin. The photographs were taken by a Laser Scaning Microscope (Zeiss Imagine Z2) (x 400), and then evaluated using the Leica Qwin image processing and analysis software. Quantifications of the AhR, ARNT, and Cypla2 immunostaining were performed by assessing the proportion of the positively-stained area in the same structures mentioned above per section. The positive cell numbers stained with AhR, ARNT, and Cyp1a2 were counted automatically in 5 areas of each photograph at a magnification of $400 \mathrm{x}$. The AhR, ARNT, and Cypla2 positive cells were expressed as numbers per field.

\section{Radioimmunoassay (RIAs)}

Female pup serum was measured for follicle-stimulating hormone (FSH), luteinizing hormone ( $\mathrm{LH})$ and estradiol-17 $($ E2) by a liquid phase order saturated immune RIA kit (DPC, Tianjin, China). Female adult serum was measured for E2 and progesterone (PGN) using a double-antibody RIA kit (DPC). FSH, LH, E2 and PGN levels were determined using materials supplied by Radiological Inspection Center of the People's First Hospital of Guangzhou City. The sensitivities of the assays for FSH, LH, and E2 and PGN were $0.1 \mathrm{ml} \mathrm{U} / \mathrm{ml}, 15 \mathrm{pg} / \mathrm{ml}$, and $0.2 \mathrm{ng} / \mathrm{ml}$, respectively.

\section{Statistical analyses}

Prior to the analysis, the normality of the data was determined using the one sample Kolmogorov-Smirnov Test. Reproductive indices (time to mating, litter weight), the positive area and absorbance of AhR, ARNT, Cyp1a2 were analyzed using One-Way ANOVA by Post Hoc Multiple Comparisons. Reproductive indices (i.e., time to mating, fertility, gestation, gestation length, litter number, pup survive), body weight, serum steroid hormone were analyzed using the Mann Whitney $U$ Test. The sex ratio was calculated for the weaned and young mice in each litter by the following formula: male/(male + female) $\mathrm{x}$ $100 \%$. TCDD equivalence levels of sample water were analyzed using Paired-Samples T Test. Data are presented as mean \pm S.E.M. All calculations and statistical analysis were generated in SPSS 16 for windows. 
The low level of TCDD-like activity in drainage canal water causes high postnatal mortality in mice

\section{RESULTS}

\section{TCDD equivalence levels of sample water}

The water samples for the three-generation experiment were collected and assayed, containing 3.24 and $1.94 \mathrm{ng} / \mathrm{l}$ TCDD-like contaminant in 2004 with Yeast reporter (Li et al., 2004). Therefore, $2 \mathrm{ng} / 1$ TCDD was used as positive TCDD standard water which is similar in concentration to Fangcun sample water. After the experiment, water samples used in this experiment were reevaluated, along with water samples collected from same sites using the same reporter system in year 2010. Fig. 2 shows TCDD equivalence in the samples calculated from the relative AhRdriven reporter-activating activity based on the standard curve, which showed a straight linear correlation value of 0.91 in the range of 0.03-10 ng/1 TCDD. The Shijin, Fangcun water samples and 2 ng/1 TCDD of year 2004 induced lacZ activity levels equivalent to $3.10,1.54$ and $2.39 \mathrm{ng} / 1$ TCDD, respectively, while that of Shijin and Fangcun water samples in 2010 and 2 ng/1 TCDD are $1.57,1.12$ and $1.94 \mathrm{ng} / \mathrm{l}$. There is no significance of difference in all water samples except Shijing River $(\mathrm{p}<0.05)$ between 2004 and 2010. The tap water also showed slight increased lac Z expression, but it was below the range of the standard curve and may not be accurate at this level.

\section{Reproductive performance}

There were no treatment-related clinical signs noted during the pre-mating periods in the $\mathrm{P} 0, \mathrm{P} 1$ or $\mathrm{P} 2$ adult mice exposed to the water samples and the TCDD standard water. However, miscarriages were noted during early gestation in the TCDD standard water and two test water groups in all generations, such as vaginal bleeding. Stillbirth rates were increased with the test water in both the P1 and P2 generations. Blindness was noted in the TCDD standard group in 2 pups, and in 2 female pups in the F3 generation that were treated with the Fangcun water. Slow fur growth was noted during lactation in the test water group in F3 generations. Hydrocephalus was noted in 2 pups in the TCDD standard sample group and in 2 pups in the Fangcun water group in the F3 generation. Therefore, the increased incidences of miscarriage, still-birth, blindness, feather growth and hydrocephalus were considered the evidence of treatment-related maternal effects.

Reproductive indices for the 6 matings (F1a, F1b, F2a, F2b, F3a and F3b) across the 3 generations are summarized in Table 1. The Mean Day to Mating and Gestation Length were significantly prolonged in groups drinking the water samples and TCDD standard water compared to control values in the $\mathrm{P} 0, \mathrm{P} 1$ and $\mathrm{P} 2$ generations $(\mathrm{p}<$ $0.05,0.01,0.001$, respectively). Female Fertility Index and Gestation Index in treated groups were generally lower than in the control animals, but with different patterns among the groups. Statistically significant decreases in the Female Fertility Index were limited in groups treated with the TCDD water in the P2 generation $(\mathrm{p}<$

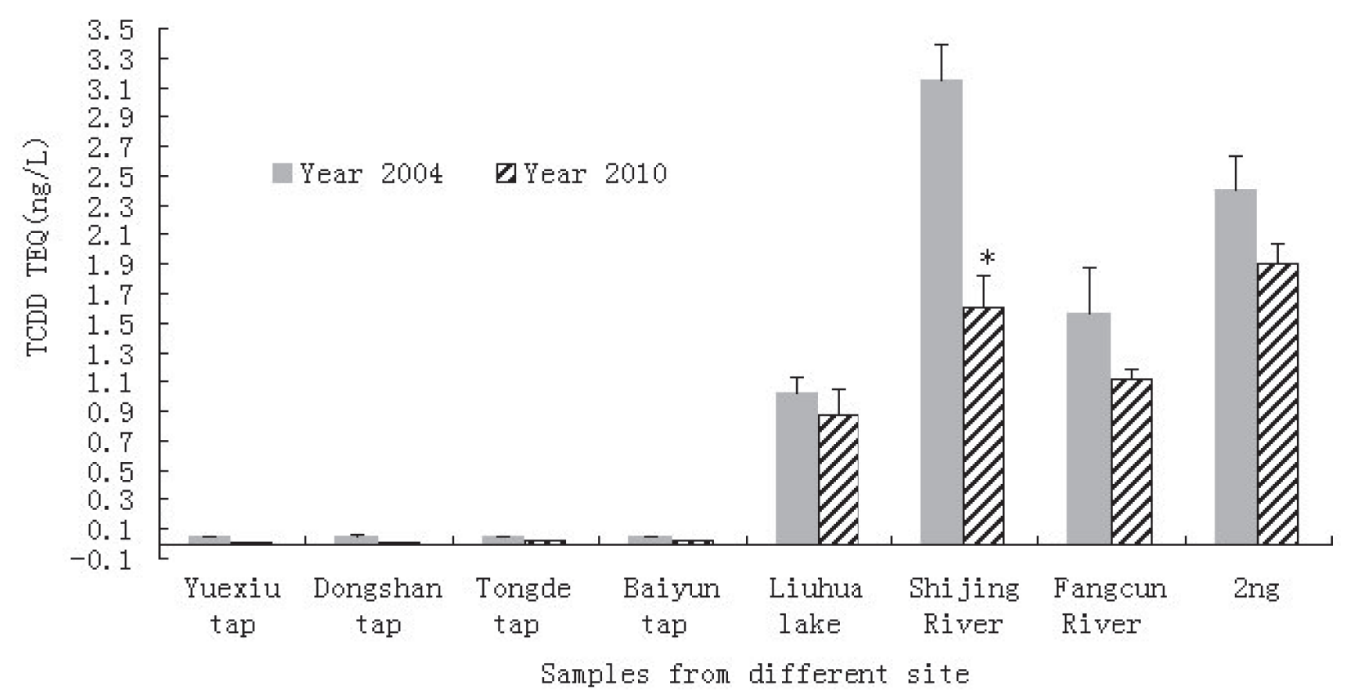

Fig. 2. TCDD equivalence (TEQ) of different water samples assayed using the AhR-driven lacZ reporter system. The water samples were collected in 2004 (Year 2004) and 2010 (Year 2010) at the same sites of Shijing and Fongcun River, as well as Liuhua Lake water sample (not used in the chonic experiment) assayed at the end of experiment. All data were from four times repeated assays. $* \mathrm{P}<0.05$ compared with data in 2004 year. 
Table 1. Comparison of the three-generation reproduction indices related to drinking contaminated water

\begin{tabular}{|c|c|c|c|c|c|}
\hline \multirow{2}{*}{ Trearment } & \multirow[b]{2}{*}{ Generation } & \multicolumn{4}{|c|}{ Contaminant Water Samples } \\
\hline & & $\begin{array}{c}\text { Control } \\
30\end{array}$ & $\begin{array}{c}2 \mathrm{ng} / \mathrm{l} \mathrm{TCDD} \text { water } \\
30\end{array}$ & $\begin{array}{c}\text { Shijing water } \\
30\end{array}$ & $\begin{array}{c}\text { Fangcun water } \\
30\end{array}$ \\
\hline Mean day to mating (d) & $\begin{array}{l}\text { P0 (F1a-F1b) } \\
\text { P1 (F2a-F2b) } \\
\text { P2 (F3a-F3b) }\end{array}$ & $\begin{array}{l}4.10 \pm 0.51 \\
3.90 \pm 0.99 \\
4.88 \pm 0.26\end{array}$ & $\begin{array}{l}12.44 \pm 1.48^{* * *} \\
10.50 \pm 1.56^{*} \\
11.37 \pm 0.91^{* * *}\end{array}$ & $\begin{aligned} 11.30 & \pm 1.46^{* *} \\
9.22 & \pm 1.64^{* *} \\
12.2 & \pm 1.01^{* * *}\end{aligned}$ & $\begin{aligned} 11.00 & \pm 2.41^{* *} \\
10.14 & \pm 0.93^{* * *} \\
8.28 & \pm 1.47^{*}\end{aligned}$ \\
\hline $\begin{array}{l}\text { Female mating } \\
\text { index }(\%)\end{array}$ & $\begin{array}{l}\text { P0(F1) } \\
\text { P1(F2) } \\
\text { P2(F3) }\end{array}$ & $\begin{array}{l}100 \\
100 \\
100\end{array}$ & $\begin{array}{c}100 \\
90.00 \pm 5.57 \\
84.62 \pm 7.48\end{array}$ & $\begin{aligned} 96.15 & \pm 3.84 \\
88.88 & \pm 6.16 \\
87.5 & \pm 5.93\end{aligned}$ & $\begin{array}{l}92.00 \pm 5.53 \\
92.31 \pm 5.75 \\
90.32 \pm 6.1\end{array}$ \\
\hline Female fertility index (\%) & $\begin{array}{l}\text { P0(F1)) } \\
\text { P1(F2) } \\
\text { P2(F3) }\end{array}$ & $\begin{array}{l}92.00 \pm 5.54 \\
95.00 \pm 5.00 \\
95.23 \pm 4.76\end{array}$ & $\begin{aligned} 87.5 & \pm 6.89 \\
83.33 & \pm 6.92 \\
80.00 & \pm 8.16^{*}\end{aligned}$ & $\begin{array}{l}84.62 \pm 7.21^{*} \\
79.46 \pm 8.16^{*} \\
67.85 \pm 8.98^{* *}\end{array}$ & $\begin{array}{l}64.00 \pm 8.98^{*} \\
72.41 \pm 8.44^{*} \\
58.06 \pm 9.01^{* *}\end{array}$ \\
\hline Gestation index (\%) & $\begin{array}{l}\mathrm{P} 0(\mathrm{~F} 1)) \\
\mathrm{P} 1(\mathrm{~F} 2) \\
\mathrm{P} 2(\mathrm{~F} 3)\end{array}$ & $\begin{array}{l}88.00 \pm 6.63 \\
95.00 \pm 5.00 \\
95.00 \pm 5.00\end{array}$ & $\begin{array}{l}70.83 \pm 9.47 \\
72.41 \pm 8.44 \\
72.00 \pm 9.16^{*}\end{array}$ & $\begin{array}{l}79.16 \pm 8.46 \\
79.16 \pm 8.46 \\
56.52 \pm 10.56^{* *}\end{array}$ & $\begin{array}{l}54.16 \pm 10.38^{*} \\
53.57 \pm 9.59^{*} \\
55.55 \pm 12.05 * *\end{array}$ \\
\hline Gestation length (day) & $\begin{array}{l}\text { P0(F1) } \\
\text { P1(F2) } \\
\text { P2(F3) }\end{array}$ & $\begin{array}{l}19.17 \pm 0.12 \\
19.17 \pm 0.09 \\
19.18 \pm 0.13\end{array}$ & $\begin{array}{l}20.13 \pm 0.0 .08^{* * *} \\
20.10 \pm 0.10^{* * *} \\
19.79 \pm 0.09^{* *}\end{array}$ & $\begin{array}{l}19.95 \pm 0.12^{* * *} \\
20.00 \pm 0.07 * * * \\
19.67 \pm 0.13^{*}\end{array}$ & $\begin{array}{l}20.13 \pm 0.09 * * * \\
19.63 \pm 0.13^{*} \\
20.00 \pm 0.14^{* * *}\end{array}$ \\
\hline $\begin{array}{l}\text { Day } 1 \text { pup survival (Live } \\
\text { Birth) index }(\%)\end{array}$ & $\begin{array}{l}\text { P0(F1) } \\
\text { P1(F2) } \\
\text { P2(F3) }\end{array}$ & $\begin{array}{c}98.39 \pm 1.15 \\
100 \\
100\end{array}$ & $\begin{array}{l}95.57 \pm 3.20 \\
93.79 \pm 4.04 \\
92.03 \pm 4.90\end{array}$ & $\begin{array}{l}96.44 \pm 1.67 \\
89.68 \pm 5.82 \\
90.83 \pm 5.33\end{array}$ & $\begin{array}{l}96.11 \pm 1.94 \\
89.14 \pm 5.15 \\
87.40 \pm 7.56\end{array}$ \\
\hline $\begin{array}{l}\text { Day } 4 \text { pup survival index } \\
(\%)\end{array}$ & $\begin{array}{l}\text { P0(F1) } \\
\text { P1(F2) } \\
\text { P2(F3) }\end{array}$ & $\begin{array}{l}92.14 \pm 6.25 \\
95.69 \pm 2.04 \\
89.15 \pm 3.40\end{array}$ & $\begin{array}{l}79.58 \pm 7.62 \\
51.51 \pm 10.86^{* * \Delta} \\
49.48 \pm 10.12^{* * \Delta \Delta}\end{array}$ & $\begin{array}{l}83.90 \pm 6.90 \\
69.28 \pm 9.62 * \Delta \\
71.04 \pm 9.60 * \Delta\end{array}$ & $\begin{array}{c}74.12 \pm 8.20^{*} \\
60.59 \pm 9.72^{*} \\
67.662 \pm 10.00^{*}\end{array}$ \\
\hline $\begin{array}{l}\text { Day } 21 \text { pup survival } \\
\text { (Weaning) index (\%) }\end{array}$ & $\begin{array}{l}\text { P0(F1) } \\
\text { P1(F2) } \\
\text { P2(F3) }\end{array}$ & $\begin{array}{l}92.14 \pm 6.24 \\
95.43 \pm 1.98 \\
89.15 \pm 2.04\end{array}$ & $\begin{array}{l}77.26 \pm 7.18 \\
49.07 \pm 9.54^{* * \Delta} \\
41.34 \pm 8.66^{* * * \Delta \Lambda}\end{array}$ & $\begin{array}{l}81.65 \pm 7.11 \\
59.01 \pm 8.39 * \Delta \\
57.75 \pm 9.34 * \Delta\end{array}$ & $\begin{array}{l}72.20 \pm 8.90^{*} \\
60.59 \pm 9.72^{*} \\
67.66 \pm 10.00^{*}\end{array}$ \\
\hline Sex rate $(\precsim \%)$ & $\begin{array}{l}\text { P0(F1) } \\
\text { P1(F2) } \\
\text { P2(F3) }\end{array}$ & $\begin{array}{l}46.60 \\
47.01 \\
50.11\end{array}$ & $\begin{array}{l}49.62 \\
55.95 \\
56.17\end{array}$ & $\begin{array}{l}45.23 \\
53.35 \\
55.00\end{array}$ & $\begin{array}{l}46.88 \\
54.73 \\
57.23\end{array}$ \\
\hline Litter number & $\begin{array}{l}\text { P0(F1) } \\
\text { P1(F2) } \\
\text { P2(F3) }\end{array}$ & $\begin{array}{l}6.06 \pm 0.56 \\
6.00 \pm 0.49 \\
5.33 \pm 0.24\end{array}$ & $\begin{array}{l}5.45 \pm 0.41 \\
5.20 \pm 0.36 \\
4.65 \pm 0.35\end{array}$ & $\begin{array}{l}5.25 \pm 0.35 \\
5.40 \pm 0.41 \\
4.00 \pm 0.42 *\end{array}$ & $\begin{array}{l}5.29 \pm 0.45 \\
5.50 \pm 0.38 \\
4.73 \pm 0.44\end{array}$ \\
\hline Litter weight $(\mathrm{g})$ & $\begin{array}{l}\text { P0(F1) } \\
\text { P1(F2) } \\
\text { P2(F3) }\end{array}$ & $\begin{array}{l}7.79 \pm 0.62 \\
7.72 \pm 0.65 \\
6.66 \pm 0.38\end{array}$ & $\begin{array}{l}7.57 \pm 0.56 \\
6.39 \pm 0.40 \\
5.36 \pm 0.43 \Delta\end{array}$ & $\begin{array}{l}6.94 \pm 0.53 \\
6.92 \pm 0.50 \\
5.45 \pm 0.53 \wedge\end{array}$ & $\begin{array}{l}7.09 \pm 0.62 \\
7.45 \pm 0.54 \\
6.00 \pm 0.58\end{array}$ \\
\hline Birth weight(g) & $\begin{array}{l}\text { P0(F1) } \\
\text { P1(F2) } \\
\text { P2(F3) }\end{array}$ & $\begin{array}{l}1.2982 \pm 0.0188 \\
1.3034 \pm 0.0120 \\
1.3148 \pm 0.0158\end{array}$ & $\begin{array}{l}1.3655 \pm 0.0115 \\
1.3343 \pm 0.0207 \\
1.2451 \pm 0.0305\end{array}$ & $\begin{array}{l}1.3609 \pm 0.0104 \\
1.3599 \pm 0.0165 \\
1.3276 \pm 0.0128\end{array}$ & $\begin{array}{l}1.3325 \pm 0.0126 \\
1.2989 \pm 0.0165 \\
1.2693 \pm 0.0268\end{array}$ \\
\hline D7 weight(g) & $\begin{array}{l}\text { P0(F1) } \\
\text { P1(F2) } \\
\text { P2(F3) }\end{array}$ & $\begin{array}{l}4.1095 \pm 0.1941 \\
4.0251 \pm 0.1736 \\
4.5970 \pm 0.2350\end{array}$ & $\begin{array}{l}4.0900 \pm 0.0707 \\
3.8858 \pm 0.1140 \\
3.9961 \pm 0.1274\end{array}$ & $\begin{array}{l}3.6768 \pm 0.0911 \\
3.7768 \pm 0.1647 \\
3.5010 \pm 0.0562 *\end{array}$ & $\begin{array}{l}4.0215 \pm 0.1158 \\
3.7649 \pm 0.1752 \\
3.7354 \pm 0.0855\end{array}$ \\
\hline D14 weight(g) & $\begin{array}{l}\text { P0(F1) } \\
\text { P1(F2) } \\
\text { P2(F3) }\end{array}$ & $\begin{array}{l}6.3179 \pm 0.1672 \\
6.3592 \pm 0.1935 \\
6.5639 \pm 0.1900\end{array}$ & $\begin{array}{l}6.1091 \pm 0.274 \\
6.3112 \pm 0.2742 \\
6.4546 \pm 0.1228\end{array}$ & $\begin{array}{l}6.2445 \pm 0.1929 \\
5.9173 \pm 0.2742 \\
6.1641 \pm 0.1228\end{array}$ & $\begin{array}{l}6.2584 \pm 0.2772 \\
6.3166 \pm 0.2812 \\
6.4670 \pm 0.1352\end{array}$ \\
\hline D21 weight $(g)$ & $\begin{array}{l}\text { P0(F1) } \\
\text { P1(F2) } \\
\text { P2(F3) }\end{array}$ & $\begin{array}{l}8.5557 \pm 0.2442 \\
8.5220 \pm 0.3412 \\
9.4681 \pm 0.1521\end{array}$ & $\begin{array}{l}8.5054 \pm 0.2801 \\
8.6414 \pm 0.3451 \\
8.1996 \pm 0.3712\end{array}$ & $\begin{aligned} 8.5229 & \pm 0.3578 \\
8.4387 & \pm 0.2459 \\
8.533 & \pm 0.2516\end{aligned}$ & $\begin{array}{l}8.6490 \pm 0.3425 \\
8.4559 \pm 0.2476 \\
8.3043 \pm 0.2900\end{array}$ \\
\hline
\end{tabular}

The data are presented as mean \pm S.E.M. $(\mathrm{n}=20) . * \mathrm{P}<0.05$ compared to the control water group; $* * \mathrm{P}<0.01$ compared to thecontrol water group; and ${ }^{* * *} \mathrm{P}<0.001$ compared to the control water group. $\mathbf{\Delta} \mathrm{P}<0.05$ compared to the first generation $(\mathrm{F} 1) ; \mathbf{\Delta} \mathbf{\Delta} \mathrm{P}<0.001$ compared to the first generation (F1). 
The low level of TCDD-like activity in drainage canal water causes high postnatal mortality in mice

0.05). While in the Shijing and Fangchun waters groups, this happened across all three generations $(\mathrm{p}<0.05,0.05$, 0.01). Significant decreases of Gestation Index were limited in groups treated with the TCDD water and Shijing water in the P2 generation $(\mathrm{p}<0.05,0.01)$, while Fangcun water treatment significant decreased across all three generations $(\mathrm{p}<0.05,0.05,0.01)$. The Mating Index had not been altered in any group of experiment.

\section{Developmental performance in F1, F2 and F3 pups}

Treatment-related effects in the pups were related to survival index. Statistically lower pup survival indices were noted on days 4 and 21 in the F2 and F3 generations exposed to the TCDD standard water $(\mathrm{P}<0.01)$ and the Shijing water $(\mathrm{P}<0.05)$, compare with both $\mathrm{F} 1$ generation and drink tap water, which were significantly lower in all 3 generations $(\mathrm{P}<0.05)$ in animals drinking Fangcun water. These indices were reflective of effects across a number of litters, and were thus considered treatmentrelated. There is no significant statistic difference in the litter number except for F3 generation in Shijing water group. The sex ratios and litter weights didn't change in any generation among the treatment groups. Lower day 7 pup body weights compared to controls were noted in the F3 generation $(\mathrm{p}<0.05)$ exposed to Shijing water but cannot be proved to be treatment-related.

\section{Serum hormone levels from multiparous and virgin females with test-water treatment}

Serum hormone levels were assayed after weaning day 35. The estrogen levels from the multiparous females were significantly decreased on $\mathrm{P} 0$ generation in the two sample waters and TCDD exposure groups( $p<0.05)$, and on P1 generation in the TCDD water and Shijing water $(\mathrm{p}<0.05)$ comparison to controls (Fig. 3A). The progesterone levels were not changed across three generation. The levels of LH and FSH in the virgin females were significantly decreased in the two test and TCDD water of F2 and F3 generations, but not in F1. Figure 3B showed that the estrogen level from the virgin females were significantly decreased in the two test water exposure groups of F1 and F3, as similar as in TCDD groups.

\section{Immunochemical staining of TCDD exposure-related biomarkers}

The enzyme Cyp1a2, which is involved in TCDD metabolism and recognized as a typical biomarker, can be induced by TCDD exposure. It is reported that AhR and ARNT are TCDD receptors and TCDD-related nuclear-transport proteins, and can be induced by TCDD expo-
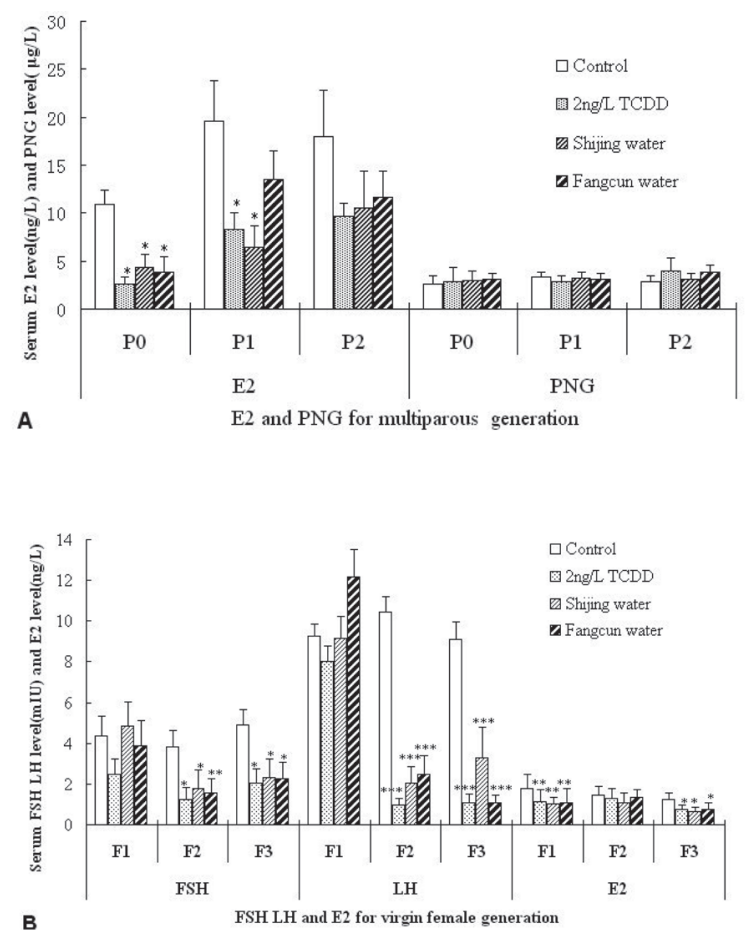

Fig. 3. A. Hormone levels for multiparous females after weaning day 35 . B. Hormone levels for virgin females after weaning day $35 . * \mathrm{P}<0.05$ compared to the control group; $* * \mathrm{P}<0.01$ compared to the negative control group; and $* * * \mathrm{P}<0.001$ compared to the control group.

sure. Using immunohistochemistry, we identified and localized these proteins. The AhR-rich cells were stained dark brown and readily identified. In the control groups, the endometrial and glandular epithelial cells in the uterus showed faintness AhR immunoreactivity (Fig. 4A). The TCDD standard water and the two test water showed higher intensities of AhR-positive staining (Figs. 4B-D). The optical density was significantly higher than in control groups, and the number of positive cells, measured as positive areas $(\%)$, increased significantly due to a proportion of cells in the connective tissue that expressed AhR. In addition, the positive staining area of the F2 and F3 generation in TCDD water and Shijing water were higher than F1 generation. The optical density of F3 generation in TCDD water were higher than the F1 generation (Table 2). Contrary to the AhR results, the area changes related to Cyp1a2 were similar to AhR (Figs. 4E-H). But the Cyp1a2 protein-positive area showed a tendency to decrease from F1 to F3 generation, and F3 was lower than F1 in TCDD water (Table 2). Shijing and Fang- 


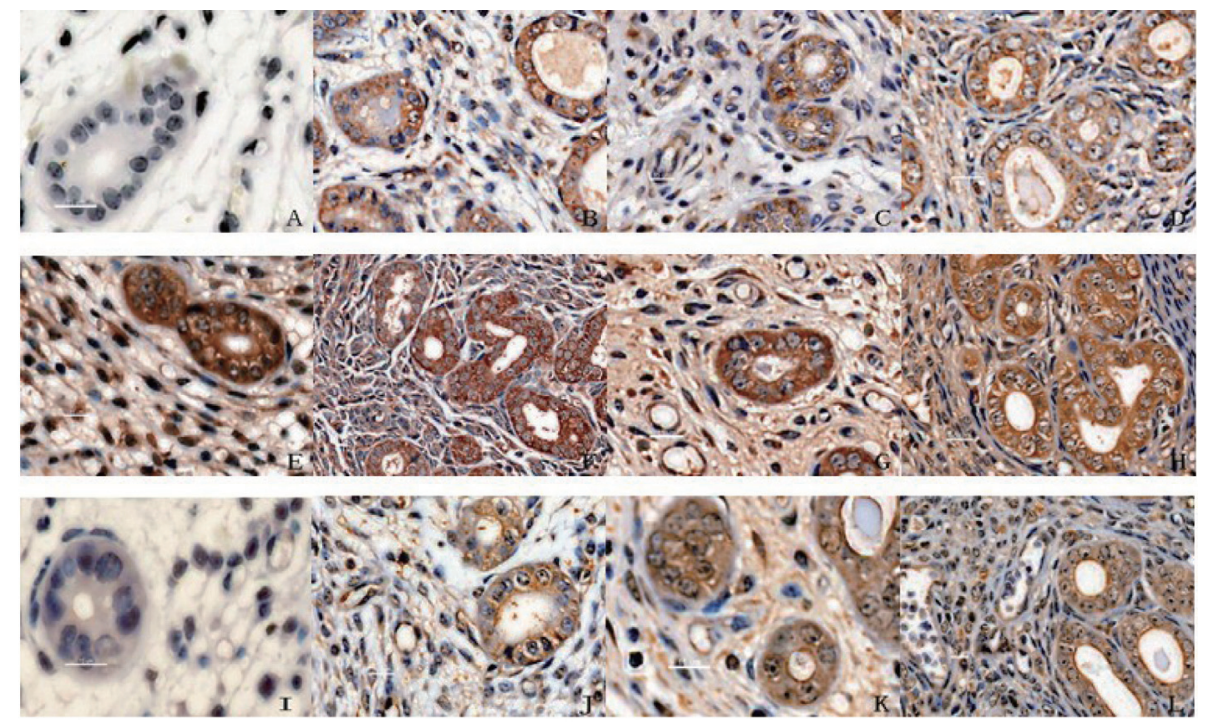

Fig. 4. Typical immunochemical staining images of Ahr, ARNT and Cyp1a2 in the uteri of mice drinking tap water (column 1), TCDD standard sample (column 2), Shijing wastewater (column 3) or Fangcun wastewater (column 4). ob, $\times 40$, Bar $=15 \mu \mathrm{m}$.

Table 2. Effects of contaminated water on the distribution of proteins in uterus tissue from C57BL/6J mice exposed to contaminated water

\begin{tabular}{|c|c|c|c|c|c|c|}
\hline $\begin{array}{c}\text { Receptor } \\
\text { protein }\end{array}$ & Generation & & Control water & 2ng/l TCDD water & Shijing water & Fangcun water \\
\hline \multirow{6}{*}{ Ahr } & \multirow{2}{*}{$\mathrm{F} 1$} & Areas $(\%)$ & $5.00 \pm 0.96$ & $11.23 \pm 1.08^{* *}$ & $8.01 \pm 1.07$ & $9.58 \pm 1.22 *$ \\
\hline & & OD & $0.21 \pm 0.01$ & $0.31 \pm 0.01 * * *$ & $0.34 \pm 0.01 * * *$ & $0.44 \pm 0.02 * * *$ \\
\hline & \multirow{2}{*}{$\mathrm{F} 2$} & Areas $(\%)$ & $5.00 \pm 0.96$ & $16.08 \pm 2.58^{* * * \Delta}$ & $14.13 \pm 1.42 * * * \Delta \mathbf{\Delta}$ & $10.41 \pm 0.80^{* *}$ \\
\hline & & OD & $0.21 \pm 0.01$ & $0.34 \pm 0.02 * * *$ & $0.32 \pm 0.01 * * *$ & $0.39 \pm 0.03 * * *$ \\
\hline & \multirow{2}{*}{ F3 } & Areas & $5.00 \pm 0.96$ & $17.38 \pm 1.35^{* * * \Delta \mathbf{\Delta}}$ & $13.96 \pm 1.40 * * * \Delta \mathbf{\Delta}$ & $8.62 \pm 1.58 *$ \\
\hline & & OD & $0.21 \pm 0.01$ & $0.38 \pm 0.02 * * * \boldsymbol{\Delta}$ & $0.32 \pm 0.01^{* * *}$ & $0.33 \pm 0.01 * * *$ \\
\hline \multirow{6}{*}{ Arnt } & \multirow{2}{*}{ F1 } & Areas $(\%)$ & $6.14 \pm 0.67$ & $12.12 \pm 3.44$ & $10.53 \pm 2.08$ & $9.71 \pm 0.77$ \\
\hline & & OD & $0.45 \pm 0.02$ & $0.32 \pm 0.02 * * *$ & $0.32 \pm 0.01 * * *$ & $0.31 \pm 0.01 * * *$ \\
\hline & \multirow{2}{*}{$\mathrm{F} 2$} & Areas $(\%)$ & $6.14 \pm 0.67$ & $8.2 \pm 2.85$ & $9.48 \pm 0.72$ & $6.54 \pm 0.90$ \\
\hline & & OD & $0.45 \pm 0.02$ & $0.28 \pm 0.01 * * *$ & $0.30 \pm 0.02 * * *$ & $0.29 \pm 0.01 * * *$ \\
\hline & \multirow{2}{*}{ F3 } & Areas $(\%)$ & $6.14 \pm 0.67$ & $8.6 \pm 0.67$ & $8.71 \pm 0.79$ & $5.92 \pm 0.90$ \\
\hline & & OD & $0.45 \pm 0.02$ & $0.26 \pm 0.01 * * * \Delta$ & $0.32 \pm 0.01 * * *$ & $0.24 \pm 0.01 * * *$ \\
\hline \multirow{6}{*}{ Cyp1a2 } & \multirow{2}{*}{ F1 } & Areas $(\%)$ & $7.29 \pm 0.91$ & $18.20 \pm 3.45^{* *}$ & $16.95 \pm 2.38^{* *}$ & $19.46 \pm 2.91 * *$ \\
\hline & & OD & $0.29 \pm 0.01$ & $0.44 \pm 0.01^{* * *}$ & $0.38 \pm 0.02 * *$ & $0.34 \pm 0.02$ \\
\hline & \multirow{2}{*}{ F2 } & Areas $(\%)$ & $7.29 \pm 0.91$ & $12.58 \pm 1.32$ & $17.10 \pm 1.29 * *$ & $18.29 \pm 1.23^{* *}$ \\
\hline & & OD & $0.29 \pm 0.01$ & $0.44 \pm 0.01 * * *$ & $0.36 \pm 0.03 *$ & $0.38 \pm 0.01 * *$ \\
\hline & \multirow{2}{*}{ F3 } & Areas $(\%)$ & $7.29 \pm 0.91$ & $11.52 \pm 1.48 \boldsymbol{\Delta}$ & $17.27 \pm 3.32 * *$ & $18.9 \pm 3.43 * *$ \\
\hline & & OD & $0.29 \pm 0.01$ & $0.41 \pm 0.01 * * *$ & $0.38 \pm 0.02 * *$ & $0.34 \pm 0.01$ \\
\hline
\end{tabular}

Positive areas (\%) and Optical density (OD) in the tissues. $* \mathrm{P}<0.05$ compared to the tap water; $* * \mathrm{P}<0.01$ compared to the tap water; and $* * * \mathrm{P}<0.001$ compared to the tap water. $\mathbf{\Delta}<0.05$ compared to the first generation (F1); $\Delta \mathrm{P}<0.01$ compared to the first generation (F1).

cun water kept stable in the Cyp1a2 protein positive area. Arnt positive staining was found in the nucleus in the uteri of drinking control water (Figs. 4I-L). However, the staining intensities significantly decreased in the nucleus and increased in the cytoplasm in animals who drank the
TCDD water and the two test waters, and F3 generation was lower than F1 in TCDD water (Table 2). 
The low level of TCDD-like activity in drainage canal water causes high postnatal mortality in mice

\section{DISCUSSION}

The two water samples used in this three-generation chronic toxic study were collected from sewage canal in year 2004, assayed to contain 3.24 and $1.94 \mathrm{ng} / 1$ TCDD equivalent (Li et al., 2004), and the same water samples were reevaluated to contain 3.10 and $1.54 \mathrm{ng} / 1$ TCDD equivalent (Fig. 2). The data is quite consistant between the two assays performed while the 2010 collected Shijing water sample showed significant decrease of contaminant but still remained to a high level. $2 \mathrm{ng} / \mathrm{l}$ TCDD standard water also showed a consistent result, proving this reporter system can reliably assaying the AhR activation of waters. The TCDD level around 2 $\mathrm{ng} / \mathrm{l}$ is not reported to be toxic although AhR expression may be induced (Franc et al., 2001). It is believed that most of TCDD's toxic effects are mediated by the AhR (Moriguchi et al., 2003), and activation of this receptor represents the toxic level regardless of what chemicals are producing them. We wondered if this level of contamination would have any effects on reproduction in animals since this water covers a region where farm animals are reared. For mouse, LD50 value is $114-536 \mu \mathrm{g} / \mathrm{kg}$ (Kransler et al., 2007). There were limited reports showing different dioxin-sensitive endpoints at doses below $1 \mu \mathrm{g} / \mathrm{kg} /$ day in various animal models such as in rhesus monkey (Schantz and Bowman, 1989; Rier et al., 1993), rats (Gray et al., 1997; Wolf et al., 1999), and mice (Burleson et al., 1996). Reproductive organs and embryos are more sensitive to the hazardous effects of these chemicals (Kransler et al., 2007). A typical three-generation study in the diet showed that female reproductive performance in rats was reduced with receiving $10 \mathrm{ng} / \mathrm{kg} /$ day of TCDD (Murray et al., 1979). We previously found that a $50 \mathrm{ng} / \mathrm{kg} /$ day exposure to TCDD for 8 days inhibited the decidual cell response and the number of implanted embryos (Li et al., 2006). In the same study, we found that $2 \mathrm{ng} / \mathrm{l}$ of TCDD in free drinking water altered serum reproductive hormones in mice.

We observed that drinking both the TCDD standard water (2 ng/l) and canal water reduced reproductive and pup performances (Table 1). Mean Day to Mating and Gestation Length were altered across through 3 generations; Gestation Index and Female Fertility Index were decreased in P2. Among 10 development indices examined, Day 4 and 21 Pup Survival Index were significantly decreased in P1 and P2; Litter Weight was decreased in $\mathrm{P} 2$ compared to $\mathrm{P} 0$. This above-listed changes are associated with TCDD treatment. Compared to TCDD water treatment, mice drinking city canal water showed the same effects, including Mean Day to Mating Index, Ges- tation Length, Gestation Index, Female Fertility Index, Day 4 and 21 Pup Survival Index and Litter Weight. This similarity between sample canal water and TCDD standard indicates that the sample waters from urban canal are contaminated with similar levels of TCDD-like substances or TCDD-like activity toxic contaminants. A remarkable observation in this experiment is that mice drinking city canal water that contain TCDD-like substance showed more severe outcome than TCDD water standard. In addition to this, Fangcun water seems even more toxic, manifested by causing a decrease in Day 4, 21 Pup Survival Index in F1 generation while TCDD showed this effect in F2 and F3. This indicates that other compounds may exist in the canal water, which may exert additional or synergism effect to female reproductive and development indices.

Dioxin-like contaminants are regarded as an endocrinedisrupters with the ability to disrupt reproductive systems (Baba et al., 2005; Heiden et al., 2008; Kakeyama et al., 2008; Li et al.,1995), and reproductive hormone changes were frequently mentioned as a reason for this (Gregoraszczuk et al., 2002; Morán et al., 2003; Myllymäki et al., 2005; Matsumoto et al., 2010). In the current study, the serum estrogen levels were significantly decreased in female mice drinking TCDD or canal waters. This is in agreement with previous experiments in zebrafish (Heiden et al., 2008), rodents (Chaffin et al., 1997), and in vitro cell cultures (Moran et al., 2000). The serum FSH and LH levels were found to be significantly decreased in virgin females in F2 and F3 treated with TCDD and urban canal waters. It is reported that high doses of TCDD treatment reduced $\mathrm{FSH}$ and $\mathrm{LH}$ secretion at ovulation but induced a premature surge, suggesting adverse effects of TCDD on hypothalamus or pituitary gland (Petroff et al., 2003; Gao et al., 2000). Considering that we measured the reproductive hormones on day 35 after weaning, at a window where the animals would have sexually maturated and begun estrous cycle, the varied data may also be explained by TCDD altered maturation of female reproductive process, and hormonal levels may represent values of the different phase of estrous cycle.

TCDD-mediated toxicities are due to sustained and inappropriate AhR activation leading to deregulated physiological functions (Baba et al., 2005). Our previous results indicated that the mouse uterus accumulates TCDD to a similar level as the liver, which was higher than other tissues (Li et al., 2006). A molecular marker of AhR activation is Cypla2 (Hayes et al., 2007), which can sequestrate TCDD in tissues and is a critical factor in TCDD accumulation (Grassman et al., 1998; Miller, 1997; Hakk et al., 2009). The Cypla2 expression in the 
uterus may indicate a possible functional alteration and TCDD accumulation, as a marker of uterine malfunction and deposit. We evaluated Cyp1a2 protein levels in the uteri using immunochemical staining, along with ARNT and AhR (Fig. 4). The results showed that endometrial cells did have enhanced Cyp1a2 expression. In addition to this, AhR expression was also enhanced. This suggests that with TCDD exposure the mouse uterus is more sensitive to TCDD binding than the unexposed control, and more TCDD sequestration. Both the TCDD accumulation in the uterus and increased sensitivity of the endometrial cells to TCDD, may be the reason why the embryos are affected upon TCDD exposure.

A striking phenomena found in this experiment is the greater than half of the pups died within 4 days in the F2 and F3 generations in TCDD water and urban canal sample waters. This low dose TCDD expose have not been reported to be strong enough to produce so great impact to the pups after birth. Studies with zebrafish also showed that TCDD exposure during early life stages for one generation was sufficient to cause adverse health and reproductive effects on a second generation (Takeda et al., 2011; King et al., 2009). A reason for this sensitivity increase in successor generation may be the synergism effect of maternal poor functional uterus and of expose to relative high levels of TCDD-like substances accumulated in uterus, which may directly impact the development of fetus, as well as female reproductive hormones. Our previous results showed that the decidual cell response were dramatically inhibited after 8 days oral exposure of $50 \mathrm{ng} / \mathrm{l}$, and higher TCDD deposit in the uterus in exposed mice (Li et al., 2006). This result also showed uterine AhR and cyp1A2 expression increased, which may account for partial alteration of the uterine function. The combinational effects of uterine malfuction, higher TCDD concentration and reproductive hormonal changes (Myllymäki et al., 2005; Matsumoto et al., 2010; Morán et al., 2003; Gregoraszczuk et al., 2002) could lead to morphologic abnormality and function failure leading to high mortality in the first few days after birth.

In summary, TCDD may have hazardous effects on female mouse reproduction at low doses such as $2 \mathrm{ng} / \mathrm{l}$, a contamination level that can be found in areas of heavy industry. The mechanism of this effect at this level involves high sensitivity of female reproductive organs. This may be due to the uterus having similar TCDD metabolism enzymes, which can activate TCDD-like substance and PCBs, and accumulating these substances in the environment surrounding the developing embryos or interruptions in reproductive hormones during pregnancy. We suggest that the unban canal waters containing sub- stantial amounts of TCDD-like contaminants may impede female reproductive performance and the developing embryos. Further study will be required to determine if human reproduction may be affected similarly.

\section{ACKNOWLEDGMENTS}

This research project was supported in part by an Open Grant of Provincial Key laboratory of Experiment Animal of Guangdong Province (Grant number: 2007A060101002). The project was also supported by the Provincial Nature Science Fundation (Grant number: S201110005438). The authors are grateful to Dr. Yang Zengming at the Biology Department, Shantou University, China, for his help in English writing and technical advice, to Mr. Liao Jun and Mrs. Li Wen at the People's First Hospital of Guangzhou City for their help with tissue slide, pathological analyses, and Radioimmunoassay, and to Dr. Charles Miller III at School of Public Health and Tropical Medicine, Tulane University Health Sciences Center, New Orieans, Louisiana, for provide the Yeast Reporter System for assaying TCDD-like contaminant.

\section{REFERENCES}

Baba, T., Mimura, J., Nakamura, N., Harada, N., Yamamoto, M., Morohashi, K. and Fujii-Kuriyama, Y. (2005): Intrinsic function of the aryl hydrocarbon (dioxin) receptor as a key factor in female reproduction. Mol. Cell. Biol., 25, 10040-10051.

Birnbaum, L.S. (1994): The mechanism of dioxin toxicity: relationship to risk assessment. Environ. Health Perspect., 102, 157167.

Birnbaum, L.S. and Tuomisto, J. (2000): Non-cancer effects of dioxins. Food Addit. Contam., 17, 275-288.

Bock, K.W. and Köhle, C. (2006): Ah receptor: dioxin-mediated toxic responses as hints to deregulated physiologic functions. Biochem. Pharmacol., 72, 393-404.

Burleson, G.R., Lebrec, H., Yang, Y.G., Ibanes, J.D., Pennington, K.N. and Birnbaum, L.S. (1996): Effect of 2,3,7,8-tetrachlorodibenzo-p-dioxin (TCDD) on influenza virus host resistance in mice. Fundam. Appl. Toxicol., 29, 40-47.

Chaffin, C.L., Trewin, A.L., Watanabe, G., Taya, K. and Hutz, R.J. (1997): Alterations to the pituitary-gonadal axis in the peripubertal female rat exposed in utero and through lactation to 2,3,7,8-tetrachlorodibenzo-p-dioxin. Biol. Reprod., 56, 14981502 .

Couture, L.A., Abbott, B.D. and Birnbaum, L.S. (1990): A critical review of the developmental toxicity and teratogenicity of 2,3,7,8-tetrachlorodibenzo-p-dioxin: recent advances toward understanding the mechanism. Teratology, 42, 619-627.

DeVito, M.J. and Birnbaum, L.S. (1994): Toxicology of dioxins and related compounds(M). In: Schecter A, editor. Dioxins and health. NewYork: PlenumPress.

Fenton, S.E., Hamm, J.T., Birnbaum, L.S. and Youngblood, G.L. (2002): Persistent abnormalities in the rat mammary gland following gestational and lactational exposure to 2,3,7,8-tetrachlorodibenzo-p-dioxin (TCDD). Toxicol. Sci., 67, 63-74. 
The low level of TCDD-like activity in drainage canal water causes high postnatal mortality in mice

Franc, M.A., Pohjanvirta, R., Tuomisto, J. and Okey, A.B. (2001): Persistent, low-dose 2,3,7,8-tetrachlorodibenzo-p-dioxin exposure: effect on aryl hydrocarbon receptor expression in a dioxinresistance model. Toxicol. Appl. Pharmacol., 175, 43-53.

Gao, X., Petroff, B.K., Rozman, K.K. and Terranova, P.F. (2000): Gonadotropin-releasing hormone $(\mathrm{GnRH})$ partially reverses the inhibitory effect of 2,3,7,8-tetrachlorodibenzo-p-dioxin on ovulation in the immature gonadotropin-treated rat. Toxicology, 147, $15-22$.

Grassman, J.A., Masten, S.A., Walker, N.J. and Lucier, G.W. (1998): Animal models of human response to dioxins. Environ. Health Perspect., 106, 761-775.

Gray, L.E., Ostby, J.S. and Kelce, W.R. (1997): A dose-response analysis of the reproductive effects of a single gestational dose of 2,3,7,8-tetrachlorodibenzo-p-dioxin in male Long Evans Hooded rat offspring. Toxicol. Appl. Pharmacol., 146, 11-20.

Gregoraszczuk, E.L. (2002): Dioxin exposure and porcine reproductive hormonal activity. Cad. Saude. Publica., 18, 453-462.

Guo, Y., Hendrickx, A.G., Overstreet, J.W., Dieter, J., Stewart, D., Tarantal, A.F., Laughlin, L. and Lasley, B.L. (1999): Endocrine biomarkers of early fetal loss in cynomolgus macaques (Macaca fascicularis) following exposure to dioxin. Biol. Reprod., 60, 707-713.

Hakk, H., Diliberto, J.J. and Birnbaum, L.S. (2009): The effect of dose on 2,3,7,8-TCDD tissue distribution, metabolism and elimination in CYP1A2 (-/-) knockout and C57BL/6N parental strains of mice. Toxicol. Appl. Pharmacol., 241, 119-126.

Hankinson, O. (1995): The aryl hydrocarbon receptor complex. Annu. Rev. Pharmacol. Toxicol., 35, 307-340.

Hayes, K.R., Zastrow, G.M., Nukaya, M., Pande, K., Glover, E., Maufort, J.P., Liss, A.L., Liu, Y., Moran, S.M., Vollrath, A.L. and Bradfield, C.A. (2007): Hepatic transcriptional networks induced by exposure to 2,3,7,8-tetrachlorodibenzo-p-dioxin. Chem. Res. Toxicol., 20, 1573-1581.

Heiden, T.C., Struble, C.A., Rise, M.L., Hessner, M.J., Hutz, R.J. and Carvan, M.J.3rd. (2008): Molecular targets of 2,3,7,8-tetrachlorodibenzo-p-dioxin (TCDD) within the zebrafish ovary: insights into TCDD-induced endocrine disruption and reproductive toxicity. Reprod. Toxicol., 25, 47-57.

Heimler, I., Rawlins, R.G., Owen, H. and Hutz, R.J. (1998): Dioxin perturbs, in a dose- and time-dependent fashion, steroid secretion, and induces apoptosis of human luteinizing granulosa cells. Endocrinology, 139, 4373-4379.

Holsapple, M.P., Snyder, N.K., Wood, S.C. and Morris, D.L. (1999): A review of 2,3,7,8-Tetrachlorodibenzo-p-dioxin-induced changes in immunocompetence. Toxicology, 69, 219-255.

Huang, L., Wang, J., Dai, L., Liu, H., Qiu, J., Wen, D., Feng, Y. and Li, B. (2004): Utilization of yeast gene report system to detect environmental Dioxins-like substances [J]. China J. Appl. Environ. Biol., 10, 493-496. (in Chinese)

Huisman, M., Koopman-Esseboom, C., Fidler, V., Hadders-Algra, M., van der Paauw, C.G., Tuinstra, L.G., Weisglas-Kuperus, N., Sauer, P.J., Touwen, B.C. and Boersma, E.R. (1995): Perinatal exposure to polychlorinated biphenyls and dioxins and its effect on neonatal neurological development. Early Hum. Dev., 41, 111-127.

Hutzinger, O. and Fiedler, H. (1991): Formation of dioxins and related compounds in Industrial processes. In: Bretthauer E, Kraus H, di DominicoA, editor Dioxin perspectives: a pilot study on international information exchange on dioxins and related compounds. Plenum Press.

Hurst, C.H., DeVito, M.J. and Birnbaum, L.S. (2000): Tissue dispo- sition of 2,3,7,8-tetrachlorodibenzo-p-dioxin (TCDD) in maternal and developing long-evans rats following subchronic exposure. Toxicol. Sci., 57, 275-283.

International Agency for Research on Cancer (IARC) (1997): IARC mono-graphs on the evaluation of carcinogenic risks to humans(M). International Agency for Research on Cancer; vol. 69. Polychlorinated dibenzo-para-dioxins and polychlorinated dibenzofurans. Lyon, France, IARC, 1997.

Kakeyama, M., Sone, H. and Tohyama, C. (2008): Perinatal exposure of female rats to 2,3,7,8-tetrachlorodibenzo-p-dioxin induces central precocious puberty in the offspring. J. Endocrinol., 197, 351-358.

Kang, Y., Sheng, G., Fu, J., Mai, B., Zhang, G., Lin, Zh. and Min, Y. (2000): Preliminary study of the distribution and characteristics of PCBs in some of surface sediment from Pearl River Delta. Marine Pollution. Bullinton., 40, 794-797.

King Heiden, T.C., Spitsbergen, J., Heideman, W. and Peterson, R.E. (2009): Persistent adverse effects on health and reproduction caused by exposure of zebrafish to 2,3,7,8-tetrachlorodibenzo-p-dioxin during early development and gonad differentiation. Toxicol. Sci., 109, 75-87.

Kransler, K.M., McGarrigle, B.P. and Olson, J.R. (2007): Comparative developmental toxicity of 2,3,7,8-tetrachlorodibenzo-pdioxin in the hamster, rat and guinea pig. Toxicology, 229, 214 225.

Li, B., Liu, H., Dai, L., Lu, J., Yang, Z. and Huang, L. (2006): The early embryo loss caused by 2,3,7,8-tetrachlorodibenzo-p-dioxin may be related to the accumulation of this compound in the uterus. Reprod. Toxicol., 21, 301-306.

Li, X., Johnson, D.C. and Rozman, K.K. (1995): Effects of 2,3,7, 8-tetrachlorodibenzo-p-dioxin (TCDD) on estrous cyclicity and ovulation in female Sprague-Dawley rats. Toxicol. Lett., 78, 219-222.

Matsumoto, Y., Ishida, T., Takeda, T., Koga, T., Fujii, M., Ishii, Y., Fujimura, Y., Miura, D., Wariishi, H. and Yamada, H. (2010): Maternal exposure to dioxin reduces hypothalamic but not pituitary metabolome in fetal rats: a possible mechanism for a fetusspecific reduction in steroidogenesis. J. Toxicol. Sci., 35, 365373.

Miller, C.A.3rd. (1999): A human aryl hydrocarbon receptor signaling pathway constructed in yeast displays additive responses to ligand mixtures. Toxicol. Appl. Pharmacol., 160, 297-303.

Moran, F.M., Conley, A.J., Corbin, C.J., Enan, E., VandeVoort, C., Overstreet, J.W. and Lasley, B.L. (2000): 2,3,7,8-tetrachlorodibenzo-p-dioxin decreases estradiol production without altering the enzyme activity of cytochrome $\mathrm{P} 450$ aromatase of human luteinized granulosa cells in vitro. Biol. Reprod., 62, 1102-1108.

Moran, F.M., VandeVoort, C.A., Overstreet, J.W., Lasley, B.L. and Conley, A.J. (2003): Molecular target of endocrine disruption in human luteinizing granulosa cells by 2,3,7,8-tetrachlorodibenzo-p-dioxin: inhibition of estradiol secretion due to decreased 17alpha-hydroxylase/17,20-lyase cytochrome P450 expression. Endocrinology, 144, 467-473.

Moriguchi, T., Motohashi, H., Hosoya, T., Nakajima, O., Takahashi, S., Ohsako, S., Aoki, Y., Nishimura, N., Tohyama, C., FujiiKuriyama, Y. and Yamamoto, M. (2003): Distinct response to dioxin in an arylhydrocarbon receptor (AHR)-humanized mouse. Proc. Natl. Acad. Sci. USA, 100, 5652-5657.

Murray, F.J., Smith, F.A., Nitschke, K.D., Humiston, C.G., Kociba, R.J. and Schwetz, B.A. (1979): Three-generation reproduction study of rats given 2,3,7,8-tetrachlorodibenzo-p-dioxin (TCDD) in the diet. Toxicology and Applied Pharmacology, 50, 
L. Huang et al.

241-252.

Myllymäki, S.A., Haavisto, T.E., Brokken, L.J., Viluksela, M., Toppari, J. and Paranko, J. (2005): In utero and lactational exposure to TCDD; steroidogenic outcomes differ in male and female rat pups. Toxicol. Sci., 88, 534-544.

Niittynen, M., Simanainen, U., Syrjälä, P., Pohjanvirta, R., Viluksela, M., Tuomisto, J. and Tuomisto, J.T. (2007): Differences in acute toxicity syndromes of 2,3,7,8-tetrachlorodibenzo-p-dioxin and 1,2,3,4,7,8-hexachlorodibenzo-p-dioxin in rats. Toxicology, 235, 39-51.

Petroff, B.K., Croutch, C.R., Hunter, D.M., Wierman, M.E. and Gao, X. (2003): 2,3,7,8-Tetrachlorodibenzo-p-dioxin (TCDD) stimulates gonadotropin secretion in the immature female Sprague-Dawley rat through a pentobarbital- and estradiol-sensitive mechanism but does not alter gonadotropin-releasinghormone $(\mathrm{GnRH})$ secretion by immortalized GnRH neurons in vitro. Biol. Reprod., 68, 2100-2106.

Rier, S.E., Martin, D.C., Bowman, R.E., Dmowski, W.P. and Becker, J.L. (1993): Endometriosis in rhesus monkeys (Macaca mulatta) following chronic exposure to 2,3,7,8-tetrachlorodibenzo-p-dioxin. Fundam. Appl. Toxicol., 21, 433-441.
Robert, M.P. (2006): Testing for reproductive toxicity (A). In: Ronald D.Hood eds development and reproductive toxicology(M). 2nd ed. CRC Press, New York, 425-488.

Safe, S.H. (1995): Modulation of gene expression and endocrine response path ways by 2,3,7,8-tetrachlorodibenzo-p-dioxin and related compounds. Pharmacol. Therap., 67, 247-281.

Safe, S.H. (1994): Polychlorinated biphenyls (PCBs):environmental impact, biochemical and toxic responses, and implications for risk assessment. Crit. Rev. Toxicol., 24, 87-149.

Schantz, S.L. and Bowman, R.E. (1989): Learning in monkeys exposed perinatally to 2,3,7,8-tetrachlorodibenzo-p-dioxin (TCDD). Neurotoxicol. Teratol., 11, 13-19.

Takeda, T., Taura, J., Fujii, M., Koga, T., Ishii, Y. and Yamada, H. (2011): The effect of maternal exposure to dioxin on fetal steroidogenesis in the steroidogenic organs. Fukuoka Igaku Zasshi, 102, 159-166.

Wolf, C.J., Ostby, J.S. and Gray, L.E.Jr. (1999): Gestational exposure to 2,3,7,8-tetrachlorodibenzo-p-dioxin (TCDD) severely alters reproductive function of female hamster offspring. Toxicol. Sci., 51, 259-264. 